\title{
Leaf nitrogen supply improves sugarcane photosynthesis under low temperature
}

\author{
G. CERQUEIRA*, M.C. SANTOS*, P.E.R. MARCHIORI ${ }^{* *}$, N.M. SILVEIRA*, E.C. MACHADO*, \\ and R.V. RIBEIRO***,+
}

Laboratory of Plant Physiology 'Coaracy M. Franco', Center for Research and Development in Ecophysiology and Biophysics, Agronomic Institute, P.O. Box 28, 13020-902, Campinas SP, Brazil

Department of Biology, Federal University of Lavras, P.O. Box 3037, 37200-000, Lavras MG, Brazil**

Laboratory of Crop Physiology (LCroP), Institute of Biology, University of Campinas, P.O. Box 6109, 13083-970,

Campinas SP, Brazil***

\begin{abstract}
This study aimed to test the hypothesis that increases in leaf nitrogen concentration would reduce the sensitivity of sugarcane photosynthesis to low temperature. IACSP95-5000 plants were grown inside a growth chamber at $30 / 20^{\circ} \mathrm{C}$ (day/night) and we evaluated the effects of leaf nitrogen spraying $\left(2.5 \%\right.$ urea) on plants facing low temperature $\left(22 / 12^{\circ} \mathrm{C}\right)$ for eight days. The leaf nitrogen supply increased leaf nitrogen concentration and plants exhibited higher leaf gas exchange as compared to nonsprayed ones. We also found higher activity of the carboxylation enzymes, Rubisco and phosphoenolpyruvate carboxylase, as well as a higher chlorophyll content in plants sprayed with nitrogen. Such enhancement of photosynthetic performance was associated with an increase in number of leaves and in total leaf area. Our results suggest that the effects of low temperature on photosynthesis of field-grown sugarcane plants could be alleviated by leaf nitrogen supply, with likely consequences for biomass production and crop yield.
\end{abstract}

Additional key words: Saccharum spp.; carboxylation; leaf gas exchange; urea; winter.

\section{Introduction}

$\mathrm{C}_{4}$ plants are rare in environments where the average air temperature is below $16^{\circ} \mathrm{C}$ during the growing season (Sage et al. 1999), possibly due to the high sensitivity of the photosynthetic metabolism to low temperatures. Although sugarcane plants exhibit high photosynthetic rates in subtropical regions, plants are also subjected to seasonal limitations such as low air temperature during the winter period. In fact, sugarcane photosynthesis increases with the temperature up to $35^{\circ} \mathrm{C}$ (Sage et al. 2013), with both photosynthesis and vegetative growth being inhibited below $15^{\circ} \mathrm{C}$ (Sales et al. 2013).

Dysfunction in photochemical and biochemical reactions are the main causes of declines in photosynthesis at low temperatures, with low phosphoenolpyruvate carboxylase (PEPC) activity being motivated by increases in its activation energy and also by its liability (Sage and Kubien 2007). Under low temperature, $C_{4}$ photosynthesis is also limited by the activity of Rubisco and by the regeneration of ribulose-1,5-bisphosphate (RuBP), phosphoenolpyruvate (PEP), and inorganic phosphorus (Sage and Kubien 2007). In general, $C_{4}$ species are intolerant to cold stress and their low Rubisco content - as compared to $\mathrm{C}_{3}$ plants - makes the adaptation and acclimation to cold difficult (Sage et al. 2008). In addition to the metabolic aspects, low photosynthetic activity at low temperature is also a consequence of stomatal closure due to changes in guard cell sensitivity to $\mathrm{CO}_{2}$ (Allen and Ort 2001).

In field-grown plants under subtropical conditions, significant reduction of light-conversion efficiency into biomass $\left(\varepsilon_{\mathrm{C}}\right)$ associated with decreases in leaf $\mathrm{N}$ concen-

\footnotetext{
Received 16 July 2018, accepted 12 September 2018.

+Corresponding author; phone: +55 19 35216214, e-mail: rvr@unicamp.br

Abbreviations: $\mathrm{Chl}$ - chlorophyll; $C_{\mathrm{i}}$ - intercellular $\mathrm{CO}_{2}$ concentration; $\mathrm{CNC}$ - culm nitrogen concentration; DM - dry mass; $E$ - transpiration rate; $\mathrm{FM}$ - fresh mass; $\mathrm{F}_{\mathrm{v}} / \mathrm{F}_{\mathrm{m}}-$ maximum quantum yield of PSII photochemistry; $g_{\mathrm{s}}-$ stomatal conductance; LNC - leaf nitrogen concentration; NPQ - nonphotochemical quenching of variable fluorescence; PEPC - phosphoenolpyruvate carboxylase; $P_{\mathrm{N}}-$ net photosynthetic rate; $P_{\mathrm{NI}}$ - integrated net photosynthetic rate; $Q$ - photosynthetically active radiation; $\mathrm{q}_{\mathrm{P}}$ - photochemical quenching of variable fluorescence; $\mathrm{RNC}$ - root nitrogen concentration; $\Delta \mathrm{F} / \mathrm{F}_{\mathrm{m}}$ ' - effective quantum yield of photochemical energy conversion in PSII. Acknowledgements: The authors acknowledge the National Council for Scientific and Technological Development (CNPq, Brazil) and the Coordination for the Improvement of Higher Education Personnel (CAPES, Brazil) for the studentships granted to GC and MCS and also the fellowships granted to NMS, ECM, and RVR. This research was partially supported by the São Paulo Research Foundation (FAPESP, Brazil, Grant nº. 2008/57495-3). The authors also thank the Espaço da Escrita - Pró-Reitoria de Pesquisa, UNICAMP - for the language services provided.
} 
tration (LNC) was reported in sugarcane during the winter season (Magalhães Filho 2014). Decreases in LNC are due to crop aging and low LNC may explain the reduced growth phenomenon found in sugarcane (Park et al. 2005, van Heerden et al. 2010). Accordingly, leaf $\mathrm{CO}_{2}$ assimilation increases with increasing LNC of sugarcane plants (Allison et al. 1997, Santos et al. 2017) as a significant fraction of leaf $\mathrm{N}$ is invested into the photosynthetic machinery. Sugarcane plants have $0.3-2.0 \%$ of $\mathrm{N}$ in dry biomass (Robinson et al. 2014), with most of $\mathrm{N}$ allocated into amino acids, proteins, amides, nucleic acids, nucleotides, and enzymes (Crawford et al. 2000, Robinson et al. 2014). A considerable fraction of leaf $\mathrm{N}$ is driven to the synthesis of the light-harvesting complexes and of carboxylation enzymes, such as Rubisco and PEPC (Crawford et al. 2000, Maranville and Madhavan 2002).

As the photosynthetic capacity and crop yield are closely related to $\mathrm{N}$ availability throughout a crop cycle (Saliendra et al. 1996, Marchiori et al. 2014), we could suggest that low LNC is one of the factors associated with low photosynthesis during sugarcane ripening, which occurs during the cold and dry winter season under subtropical conditions. Then, our aim was to test the hypothesis that increases in LNC through leaf spraying would reduce the sensitivity of sugarcane photosynthesis to low temperature, with plants showing higher $\mathrm{CO}_{2}$ assimilation and increased activities of carboxylation enzymes.

\section{Materials and methods}

Plant material and experimental strategy: Two-month old plants of sugarcane (Saccharum spp., cv. IACSP955000, supplied by the Advanced Centre for Technological Research of Sugarcane, Agronomic Institute, Ribeirão Preto SP, Brazil) were transplanted into $10-\mathrm{L}$ pots filled with soil fertilized with superphosphate $\left(375 \mathrm{mg} \mathrm{kg}^{-1}\right)$, potassium chloride $\left(125 \mathrm{mg} \mathrm{kg} \mathrm{kg}^{-1}\right.$ ), magnesium sulphate $\left(100 \mathrm{mg} \mathrm{kg}^{-1}\right)$, boric acid $\left(0.5 \mathrm{mg} \mathrm{kg}{ }^{-1}\right)$, Fe-EDTA (5 mg $\left.\mathrm{kg}^{-1}\right)$, manganese sulphate $\left(5 \mathrm{mg} \mathrm{kg}{ }^{-1}\right)$, copper sulphate (1.5 $\mathrm{mg} \mathrm{kg}^{-1}$ ), and zinc sulphate $\left(5 \mathrm{mg} \mathrm{kg}^{-1}\right)$. After transplanting, plants received two fertilizations with urea [125 mg(N) $\mathrm{kg}^{-1}$, each] in intervals of $15 \mathrm{~d}$ (Santos et al. 2017). Sugarcane plants were irrigated daily up to the maximum water holding capacity of soil.

Plants were grown under greenhouse conditions for $83 \mathrm{~d}$, where average air temperature was $27.2 \pm 5.5^{\circ} \mathrm{C}$ during the day and $18.2 \pm 2.5^{\circ} \mathrm{C}$ at night, relative air humidity (RH) was $82.5 \pm 15.3 \%$, and the maximum photo-synthetically active radiation $(Q)$ was $830 \mu \mathrm{mol}\left(\right.$ photon) $\mathrm{m}^{-2} \mathrm{~s}^{-1}$. When LNC reached $20 \mathrm{~g} \mathrm{~kg}^{-1}$ in leaves +1 [following the Kuijper numbering system (Bonnett 2014), leaf +1 is the first fully expanded leaf with visible dewlap, while leaf +3 is the third one and older than leaf +1 ], indicating $\mathrm{N}$ sufficiency for sugarcane (Santos et al. 2017), plants were placed inside a growth chamber for nine days under a thermal regime of $30 / 20^{\circ} \mathrm{C}$ (day/night). During the acclimation, a group of plants received two leaf $\mathrm{N}$ sprays (urea at $2.5 \%$ diluted in water and Triton ${ }^{\circledR}$ at $0.1 \%$ ) in two consecutive days, defining the treatment $+\mathrm{N}$. The other group of plants was sprayed two times with a solution composed by water and Triton $^{\circledR}$, being called as treatment N. At each spraying, plants received $180 \mathrm{~mL}$ of solution, corresponding to $4.5 \mathrm{~g}$ (urea) per plant.

Two days after the second $\mathrm{N}$ spray, plants were subjected to a thermal regime of $22 / 12^{\circ} \mathrm{C}$ (day/night) for eight days - time for plants reaching null values of photosynthesis. The other environmental conditions inside the growth chamber were constant, with $Q$ of $500 \mu \mathrm{mol}$ (photon) $\mathrm{m}^{-2}$ $\mathrm{s}^{-1}, \mathrm{RH}$ of $70 / 80 \%$ (day/night), and 12-h photoperiod. The temperature regimes were based on the temperatures that usually occur during the summer (warm and humid) and winter (cold and dry) seasons in São Paulo, Brazil. As the effects of increasing nitrogen on photosynthesis of plants under nonlimiting conditions are already known (Feng et al. 2012), we designed our experiment to test the working hypothesis about nitrogen effects under low temperature. Based on this, we needed plants under low temperature and supplied or not with leaf nitrogen. As this study was done inside a growth chamber (with constant environmental conditions) and the time under low temperature was relatively short ( $8 \mathrm{~d})$, measurements taken after nitrogen spraying and before reducing temperature were used as references.

Gas exchange, photochemical activity and chlorophyll (Chl) relative content: Leaf gas exchange was initially assessed (eight days before the cooling) to characterize the physiological state of sugarcane plants. After beginning the experiment, measurements were performed every two days in leaves +1 between 10:00 and 14:00 h, with an infrared gas analyzer (LI-6400, LI-COR, Lincoln NE, USA), under air $\mathrm{CO}_{2}$ concentration of 380 $\mu \mathrm{mol}\left(\mathrm{CO}_{2}\right) \mathrm{mol}^{-1}$ and $Q$ of $2,000 \mu \mathrm{mol}$ (photon) $\mathrm{m}^{-2} \mathrm{~s}^{-1}$. The $\mathrm{CO}_{2}$ assimilation $\left(P_{\mathrm{N}}\right)$, stomatal conductance $\left(g_{\mathrm{s}}\right)$, and intercellular $\mathrm{CO}_{2}$ concentration $\left(C_{\mathrm{i}}\right)$ were evaluated and the measurements registered under temporal stability and low coefficient of variation. The photochemical activity was evaluated with a modulated fluorometer (6400-40 $L C F, L I-C O R$, Lincoln NE, USA) attached to the LI-6400. The measurements of $\mathrm{Chl}$ fluorescence were taken simultaneously to the leaf gas exchange in light-adapted tissues, according to the technique of light saturation pulse $\left[630 \mathrm{~nm}, 6,000 \mu \mathrm{mol}\left(\right.\right.$ photon) $\left.\mathrm{m}^{-2} \mathrm{~s}^{-1}, 0.8 \mathrm{~s}\right]$. Such technique was also applied to dark-adapted tissues (30 $\mathrm{min})$, with the minimal $\left(\mathrm{F}_{0}\right)$ and maximal $\left(\mathrm{F}_{\mathrm{m}}\right)$ fluorescence in dark-adapted tissues and the minimal $\left[\mathrm{F}_{0}, 740 \mathrm{~nm}\right.$, $<5 \mu$ mol(photon) $\mathrm{m}^{-2} \mathrm{~s}^{-1}, 4 \mathrm{~s}$ ], maximal $\left(\mathrm{F}_{\mathrm{m}}{ }^{\prime}\right)$ and steadystate $\left(\mathrm{F}_{\mathrm{s}}\right)$ fluorescence in light-adapted tissues being used to estimate the following indices: variable fluorescence in the dark- $\left(\mathrm{F}_{\mathrm{v}}=\mathrm{F}_{\mathrm{m}}-\mathrm{F}_{\mathrm{o}}\right)$ and light-adapted $\left(\Delta \mathrm{F}=\mathrm{F}_{\mathrm{m}}{ }^{\prime}-\mathrm{F}_{\mathrm{s}}\right)$ leaves; the maximum quantum yield of PSII photochemistry $\left(\mathrm{F}_{\mathrm{v}} / \mathrm{F}_{\mathrm{m}}\right)$; and effective quantum yield of photochemical energy conversion in PSII $\left(\Delta \mathrm{F} / \mathrm{F}_{\mathrm{m}}{ }^{\prime}\right)$; the photochemical $\left[\mathrm{q}_{\mathrm{P}}=\left(\mathrm{F}_{\mathrm{m}}{ }^{\prime}-\mathrm{F}_{\mathrm{s}}\right) /\left(\mathrm{F}_{\mathrm{m}}{ }^{\prime}-\mathrm{F}_{0}{ }^{\prime}\right)\right]$ and nonphotochemical [NPQ $\left.=\left(\mathrm{F}_{\mathrm{m}}-\mathrm{F}_{\mathrm{m}}{ }^{\prime}\right) / \mathrm{F}_{\mathrm{m}}{ }^{\prime}\right]$ quenching of $\Delta \mathrm{F}$ (Roháček 2002). By using a Chl meter (CFL1030, Falker, Porto Alegre RS, Brazil), we measured the relative content of Chl $a$ and $b$ in the same leaves used for photosynthesis measurements (leaves +1 ) and also in leaves +3 . 
Nitrogen concentration in plant organs: LNC was estimated every two days in the leaves +1 and +3 through the equation: $\mathrm{LNC}=1.488+2.133 *(\mathrm{Chl} b)-0.049 *(\mathrm{Chl} b)^{2}$, in which $\mathrm{Chl} b$ is an indirect measure of $\mathrm{Chl} b$ content taken with the Chl meter model CFL1030 (Cerqueira et al. 2017). LNC measurements were taken during the cooling and also three days before leaf sprayings. Culm (CNC) and root (RNC) $\mathrm{N}$ concentrations were determined according to the Kjeldahl method (Bremner 1965), before cooling (at $\left.30 / 20^{\circ} \mathrm{C}\right)$ and eight days after cooling $\left(22 / 12^{\circ} \mathrm{C}\right)$.

Nitrate, ammonium and amino acids: Fractions of leaf +1 were collected prior $\left(30 / 20^{\circ} \mathrm{C}\right)$ and after cooling $\left(22 / 12^{\circ} \mathrm{C}\right)$, immediately frozen in liquid $\mathrm{N}$, and stored at $-80^{\circ} \mathrm{C}$. About $500 \mathrm{mg}$ of leaves were macerated in liquid $\mathrm{N}$ and then $2.5 \mathrm{~mL}$ of methanol:chloroform:water (MCW, 12:5:3) were added and mixed at room temperature for $2 \mathrm{~h}$. After this period, samples were centrifuged at $2,000 \times g$ for $5 \mathrm{~min}$. The extraction was performed once more with $2.5 \mathrm{~mL}$ of MCW, joining the supernatants. Finally, $4 \mathrm{~mL}$ of the leaf extract were taken (the remaining volume was measured and discarded) and mixed with $1 \mathrm{~mL}$ of chloroform and $1.5 \mathrm{~mL}$ of water. After phase separation $(12 \mathrm{~h})$, about $4 \mathrm{~mL}$ were collected from the superior aqueous phase and the extract was kept in water bath at $37^{\circ} \mathrm{C}$. The extracts were then concentrated by evaporation with a $\mathrm{N}_{2}$ jet in a concentrator (TE-019-E3, Tecnal, Piracicaba SP, Brazil) and stored at $-20^{\circ} \mathrm{C}$ before evaluating nitrate, ammonium and amino acids.

Nitrate concentration $\left(\mathrm{NO}_{3}^{-}\right)$was determined in accordance to Cataldo et al. (1975). $0.2 \mathrm{~mL}$ of $5 \%$ salicylic acid (salicylic acid in concentrated $\mathrm{H}_{2} \mathrm{PO}_{4}$ ) was added to $0.05 \mathrm{~mL}$ of the MCW extract. After mixing, the solution was left to stand for $20 \mathrm{~min}$ at room temperature. Then, $4.75 \mathrm{~mL}$ of $\mathrm{NaOH}(2 \mathrm{~N})$ was added, and the mixture was agitated again. After cooling at room temperature, absorbance was read at $410 \mathrm{~nm}$ with a spectrophotometer (80-2109-10, Pharmacia Biotech, Cambridge MA, UK). The standard curve of potassium nitrate was performed from 1 to $10 \mu \mathrm{mol} \mathrm{mL} \mathrm{m}^{-1}$ and the nitrate concentrations were expressed as $\mu \mathrm{mol} \mathrm{g} \mathrm{g}^{-1}$

The determination of ammonium $\left(\mathrm{NH}_{4}^{+}\right)$followed the protocol proposed by McCullough (1967) and Weatherburn (1967). In test tubes, we added $0.1 \mathrm{~mL}$ of MCW extract, $0.5 \mathrm{~mL}$ of the reagent \#1 $[0.1 \mathrm{M}$ phenol $(2.5 \mathrm{~g})$ and $170 \mu \mathrm{M}$ sodium nitroprusside $(12.5 \mathrm{mg})$ in $250 \mathrm{~mL}$ of distilled water] and $0.5 \mathrm{~mL}$ of reagent \#2 [0.125 M NaOH $(1.25 \mathrm{~g}), 0.15 \mathrm{M} \mathrm{Na}_{2} \mathrm{HPO}_{4} .12 \mathrm{H}_{2} \mathrm{O}(13.4 \mathrm{~g})$ and $\mathrm{NaOCl}$ $\left(3 \% \mathrm{Cl}_{2}, 10 \mathrm{~mL}\right)$ in a final $\left.250 \mathrm{~mL}\right]$. Then, tubes were agitated, sealed and incubated in water bath at $37^{\circ} \mathrm{C}$ for $35 \mathrm{~min}$. After cooling at room temperature, the absorbance was read at $625 \mathrm{~nm}$ (80-2109-10, Pharmacia Biotech., Cam-bridge, UK). The ammonium concentrations were calculated from the standard curve of ammonium sulphate

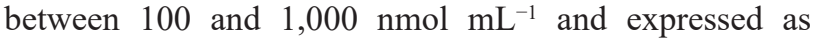
$\mu \mathrm{mol} \mathrm{g}{ }^{-1}$.

The content of amino acids was determined following the Cocking and Yemm (1954) protocol. Previously, MCW extracts were diluted in water to a final volume of $0.5 \mathrm{~mL}$ in test tubes, with the addition of $0.25 \mathrm{~mL}$ of $0.2 \mathrm{M}$ citrate buffer $(\mathrm{pH} 5.0), 0.1 \mathrm{~mL}$ of $5 \%$ ninhydrin [ninhydrin $\left(\right.$ Merck $\left.^{\mathbb{R}}\right)$ in ethylene glycol monomethyl ether (methyl cellosolve, Merck $\left.\left.{ }^{\circledR}\right)\right]$ and $0.5 \mathrm{~mL}$ of $0.01 \mathrm{M} \mathrm{KCN}$ in methyl cellosolve. The tubes were agitated, sealed, and incubated in water bath at $100^{\circ} \mathrm{C}$ for $20 \mathrm{~min}$, being cooled at room temperature. The sample was then transferred to a cuvette, adding $0.5 \mathrm{~mL}$ of $60 \%$ ethanol, and the absorbance read at $570 \mathrm{~nm}$ with a spectrophotometer (80-2109-10, Pharmacia Biotech., Cambridge, UK). The standard curve was performed with leucine 20 to $100 \mathrm{nmol} \mathrm{mL}^{-1}$, and the total soluble amino acid values were expressed as $\mu \mathrm{mol} \mathrm{g} \mathrm{g}^{-1}$.

Total soluble protein: The analysis of total soluble protein was done according to Bradford (1976) in leaf tissues sampled at $30 / 20^{\circ} \mathrm{C}$ (prior to cooling) and $22 / 12^{\circ} \mathrm{C}$ (after eight days of cooling) and stored at $-80^{\circ} \mathrm{C}$. Leaf extract was obtained with $100 \mathrm{~g}$ of fresh leaf macerated in liquid $\mathrm{N}$ with $2 \%$ polyvinylpyrrolidone (PVPP). After crushing the tissues, $2.0 \mathrm{~mL}$ of extraction buffer $[0.1$ mol L ${ }^{-1}$ potassium phosphate ( $\mathrm{pH} 6.8$ ), $0.1 \mathrm{mmol} \mathrm{L}^{-1}$ ethylenediaminetetraacetic acid (EDTA), and $1.0 \mathrm{mmol}$ $\mathrm{L}^{-1}$ phenylmethylsulfonyl fluoride (PMSF)] was added to the leaf extract and mixed for 2 min. The solution was then transferred to a tube and centrifuged at 15,000 $\times g$ at $4^{\circ} \mathrm{C}$ for $15 \mathrm{~min}$. The supernatant was collected and kept on ice. In a cuvette, we added $30 \mu \mathrm{L}$ of leaf extract, $80 \mu \mathrm{L}$ of water and $5.0 \mathrm{~mL}$ of the Bradford reagent [Comassie Blue G-250 (100 mg), 95\% ethanol (50 mL), 85\% orthophosphoric acid $(100 \mathrm{~mL})$ and distilled water $(850 \mathrm{~mL})]$. The sample absorbance was read with a spectrophotometer (Genesys 10S UV Scanning, Thermo Fisher Scientific, Madison WI, USA) at $595 \mathrm{~nm}$. Based on a standard curve with concentrations between 0 and $100 \mathrm{mg} \mathrm{mL}^{-1}$ of bovine serum albumin (BSA), the content of total soluble proteins was estimated and expressed as $\mathrm{mg} \mathrm{g}^{-1}$.

Carboxylation enzymes: Leaf samples stored at $-80^{\circ} \mathrm{C}$ were used for assessing PEPC (EC 4.1.1.31) activity according to Ashton et al. (1990) and Degl'Innocenti et al. (2002) and Rubisco (EC 4.1.1.39) activity according to Sharkey et al. (1986), Sage et al. (1988), and Reid et al. (1997). The activity of both PEPC and Rubisco were evaluated at $30 / 20^{\circ} \mathrm{C}$ (prior to cooling) and under $22 / 12^{\circ} \mathrm{C}$ (eight days after cooling).

PEPC: In a mortar, about $100 \mathrm{mg}$ of leaf +1 were macerated with liquid $\mathrm{N}$ and $2 \%$ PVPP. After grinding, $0.5 \mathrm{~mL}$ of extraction buffer $[100 \mathrm{mM}$ potassium phosphate ( $\mathrm{pH} 7.5)$ and $1 \mathrm{mM}$ EDTA] were added and macerated for $2 \mathrm{~min}$. The leaf extract was then transferred to a tube and centrifuged at $14,000 \times g$ at $4^{\circ} \mathrm{C}$ for $25 \mathrm{~min}$. The supernatant was removed and kept at $4^{\circ} \mathrm{C}$ until the analysis. The reaction buffer $[50 \mathrm{mM}$ Tris- $\mathrm{HCl}(\mathrm{pH} 7.8)$, $10 \mathrm{mM} \mathrm{NaHCO}_{3}, 5 \mathrm{mM} \mathrm{MgCl}_{2}, 5 \mathrm{mM}$ glucose 6-phosphate, 33 nKat malic dehydrogenase (MDH), and $0.3 \mathrm{mM}$ $\mathrm{NADH}$ ] was kept at $30^{\circ} \mathrm{C}$ during the analyses. In a cuvette, $800 \mu \mathrm{L}$ of reaction buffer was added to $100 \mu \mathrm{L}$ of leaf extract and $100 \mu \mathrm{L}$ of $4.0 \mathrm{mM}$ PEP. By using a spectrophotometer (Genesys 10S), the decrease in absorbance at $340 \mathrm{~nm}$ was followed for $4 \mathrm{~min}$, which reflects PEP carboxylation and 
subsequent NADH oxidation.

Rubisco: About $100 \mathrm{mg}$ of leaf +1 was also used as described for PEPC. After grinding, $0.5 \mathrm{~mL}$ of extraction buffer $\left[100 \mathrm{mM}\right.$ Bicine- $\mathrm{NaOH}(\mathrm{pH} 7.8), 5 \mathrm{mM} \mathrm{MgCl}_{2}$, $1 \mathrm{mM}$ EDTA, $5 \mathrm{mM}$ dithiothreitol (DTT), $1 \mathrm{mM}$ PMSF, and $10 \mu \mathrm{M}$ leupeptin] was added to the leaf extract and mixed. Such solution was transferred to a tube and centrifuged at $14,000 \times g$ at $4^{\circ} \mathrm{C}$ for $5 \mathrm{~min}$. The supernatant was removed and kept at $4^{\circ} \mathrm{C}$. The reaction buffer $[100 \mathrm{mM}$ Bicine$\mathrm{NaOH}$ (pH 8.0), $10 \mathrm{mM} \mathrm{NaHCO}_{3}, 20 \mathrm{mM} \mathrm{MgCl}_{2}, 3.4 \mathrm{mM}$ ATP, $5 \mathrm{mM}$ phosphocreatine, $0.25 \mathrm{mM}$ NADH, 80 nkat (4,799 U.A.) glyceraldehyde-3-phosphate dehydrogenase, 80 nkat (4.799 U.A.) creatine phosphofructokinase, and 80 nkat (4.799 U.A.) 3-phosphoglycerate phosphokinase] was kept at $25^{\circ} \mathrm{C}$ during the analyses. The initial activity of Rubisco was measured by using $900 \mu \mathrm{L}$ of the reaction buffer, $70 \mu \mathrm{L}$ of leaf extract and $30 \mu \mathrm{L}$ of $0.5 \mathrm{mM}$ RuBP added to the cuvette. Decreases in absorbance induced by NADP oxidation were followed for $3 \mathrm{~min}$ at $340 \mathrm{~nm}$, using the Genesys $10 \mathrm{~S}$ spectrophotometer. Both Rubisco and PEPC activities were expressed as $\mu \mathrm{mol} g$ (protein $)^{-1} \mathrm{~min}^{-1}$.

Biometry: Leaves and culms (main culm and tillers) were counted and plant height measured with a measuring tape. The total leaf area was determined with an electronic planimeter (LI-3000C and LI-3050C, LI-COR, Lincoln NE, USA). Leaves, culms, and roots were separated, dried in an oven with forced air circulation at $60^{\circ} \mathrm{C}$ until they reached constant mass, and then the dry matter was determined. Those evaluations were performed at the end of the experiment, i.e. after eight days under $22 / 12^{\circ} \mathrm{C}$.

Statistical analyses: The experimental design was in randomized blocks, with two causes of variation: leaf $\mathrm{N}$ supply (with and without spraying); and evaluation times $(0,2,4,6$, and $8 \mathrm{~d})$, with four replications. The data were submitted to the analysis of variance (ANOVA) and the mean values compared through the Scott Knott's test at $1 \%, 5 \%$, and $10 \%$ of significance, using the statistical software Sisvar ${ }^{\circledR}$ v.5.4 (Ferreira 2011).

\section{Results}

Gas exchange and photochemistry: $P_{\mathrm{N}}$ and $g_{\mathrm{s}}$ increased after leaf $\mathrm{N}$ spraying under adequate thermal conditions, with both variables being reduced during cooling (Fig. 1). However, decreases of $P_{\mathrm{N}}$ and $g_{\mathrm{s}}$ due to cold occurred less intensely and plants supplied with $\mathrm{N}$ exhibited higher $P_{\mathrm{N}}$ and $g_{\mathrm{s}}$ than ones nonsupplied (Fig. 1). By integrating the $\mathrm{CO}_{2}$ assimilation throughout the experimental period $\left(P_{\mathrm{NI}}\right)$, our data revealed that leaf $\mathrm{N}$ spraying reduced the sensitivity of photosynthesis to low temperature, with plants supplied with N presenting an increase of $27 \%$ in photosynthesis (Fig. 1A).

The photochemical activity was also markedly affected by low temperature, but leaf $\mathrm{N}$ supply did not alleviate the cooling effects (Fig. 2B,C). While $\mathrm{F}_{\mathrm{v}} / \mathrm{F}_{\mathrm{m}}$ was higher in $+\mathrm{N}$ plants only on the second day under low temperature (Fig. 2A), NPQ was higher in N plants on the eighth day of

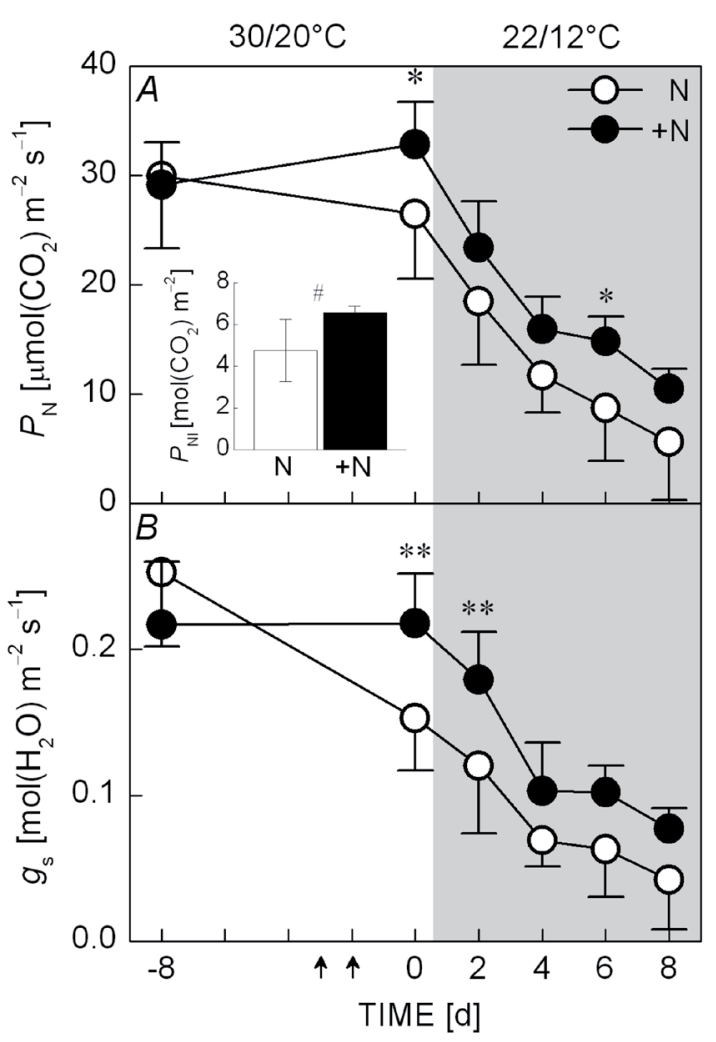

Fig. 1. Effects of leaf $\mathrm{N}$ spraying on $\mathrm{CO}_{2}$ assimilation $\left(P_{\mathrm{N}}, A\right)$ and the stomatal conductance $\left(g_{\mathrm{s}}, B\right)$ of sugarcane plants subjected to changes in growth temperature from $30 / 20^{\circ} \mathrm{C}$ to $22 / 12^{\circ} \mathrm{C}$ (day/ night). $\mathrm{CO}_{2}$ assimilation was integrated over the experimental period $\left(P_{\mathrm{NI}}\right)$ and shown in $A$. Plants were sprayed with water $(\mathrm{N})$ or $2.5 \%$ urea $(+\mathrm{N})$ in two consecutive days, indicated by arrows. Mean values ( $n=4, \pm \mathrm{SD})$ were compared by the Scott Knott's test. **, *, and $\#-$ statistical differences between the treatments in each evaluation time at $p<0.01,0.01<p<0.05$ and $0.05<p<0.10$, respectively.

cooling (Fig. 2D).

The contents of Chl $a$ and $b$ in leaves +1 and +3 increased due to leaf $\mathrm{N}$ supply before reducing temperature (time 0 ), and were not reduced during exposure to low temperature (Fig. $3 A, C$ ). In N plants, Chl $a$ and $b$ contents were reduced by low temperature and leaves +3 were more sensitive than leaves +1 .

Nitrogen: Low temperature reduced LNC in plants without extra $\mathrm{N}$ supply, and this effect was more evident in leaves +3 (Fig. 3D). Leaf $\mathrm{N}$ spray increased culm $\mathrm{N}$ concentration (CNC), but low temperature reduced $\mathrm{CNC}$ in both treatments (Fig. $3 E$ ). Interestingly, plants sprayed with $\mathrm{N}$ did not present reduction in root $\mathrm{N}$ concentration (RNC) under low temperature (Fig. $3 F$ ).

Leaf nitrate and ammonium concentrations did not vary significantly between the treatments in both temperature regimes (Table 1). On the other hand, leaf $\mathrm{N}$ supply stimulated the synthesis of total soluble amino acids before the cooling, and no significant changes were noticed for total soluble proteins (Table 1).

Carboxylation enzymes: Leaf $\mathrm{N}$ supply increased PEPC 


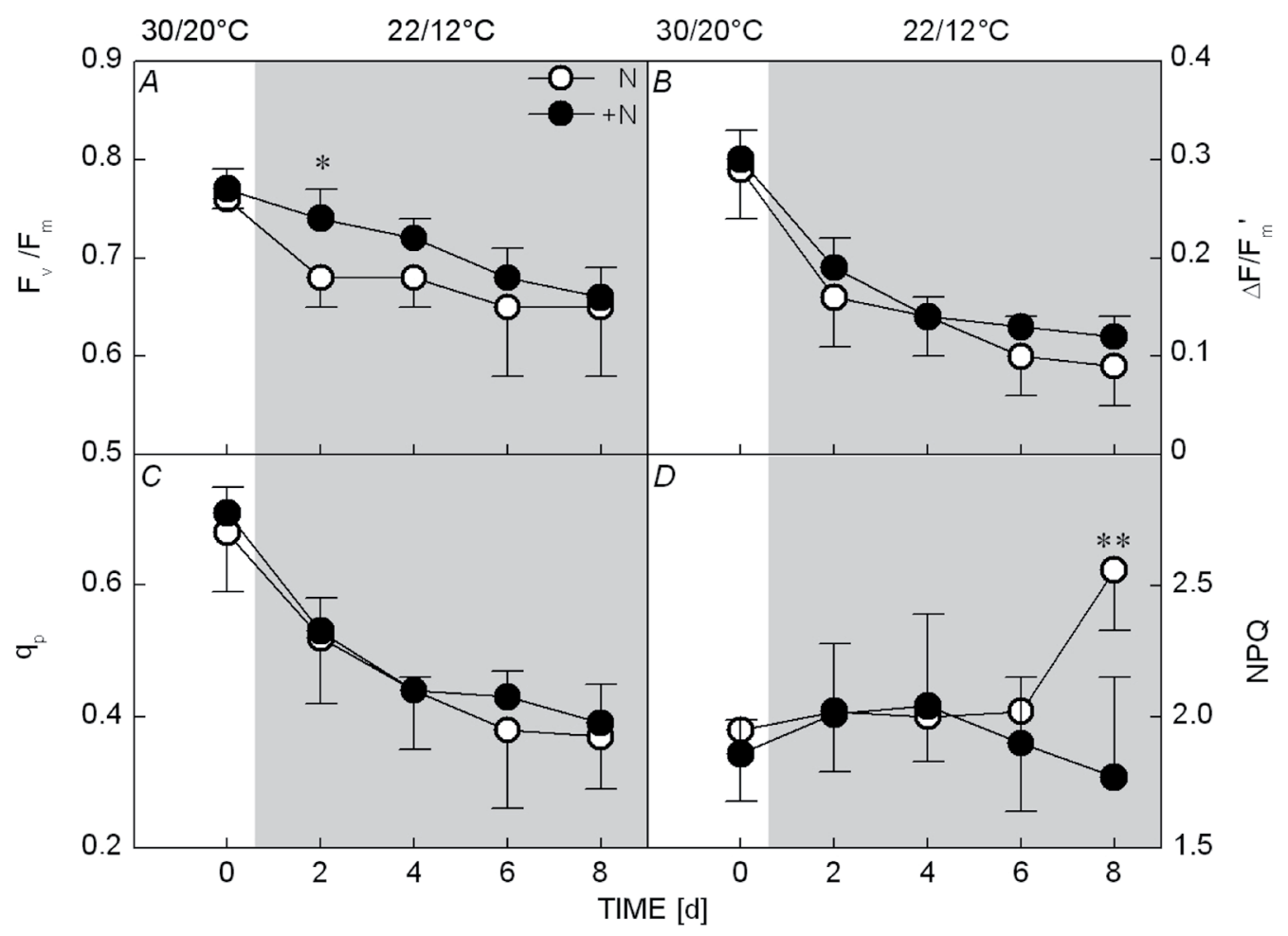

Fig. 2. Effects of leaf $N$ spraying on the maximum quantum yield of PSII photochemistry $\left(F_{v} / F_{m}\right)$, the effective quantum yield of photochemical energy conversion in PSII $\left(\Delta \mathrm{F} / \mathrm{F}_{\mathrm{m}}{ }^{\prime}\right)$; and photochemical $\left(\mathrm{q}_{\mathrm{p}}, C\right)$ and nonphotochemical $(\mathrm{NPQ}, D)$ quenching of variable fluorescence by sugarcane plants subjected to changes in growth temperature from $30 / 20^{\circ} \mathrm{C}$ to $22 / 12^{\circ} \mathrm{C}$ (day/night). Plants were sprayed with water $(\mathrm{N})$ or $2.5 \%$ urea $(+\mathrm{N})$ in two consecutive days, indicated by arrows. Mean values $(n=4, \pm \mathrm{SD})$ were compared by the $S c o t t$ Knott's test. ** and * - statistical differences between the treatments in each evaluation time at $p<0.01$ and $0.01<p<0.05$, respectively.

and Rubisco activities under both temperature regimes (Fig. 4). In addition, leaf $\mathrm{N}$ spray prevented the reduction in Rubisco activity due to low temperature (Fig. 4B).

Biometry: At the end of the experiment, leaf $\mathrm{N}$ supply caused an increase in the number of leaves, the total leaf area and plant height (Table 2). However, the number of culms and dry matter of leaves, culm and roots were not affected by leaf $\mathrm{N}$ spraying (Table 2).

\section{Discussion}

The initial hypothesis of this research was that increases in LNC could alleviate the negative impact of low temperature on sugarcane photosynthesis. Through leaf N spraying, we increased LNC and found that plants supplied with $\mathrm{N}$ presented higher photosynthesis during cold exposure when compared to plants without leaf N spraying (Fig. 1A). Such treatment allowed the maintenance of LNC during cooling, which was not observed in the plants without extra $\mathrm{N}$ supply (Fig. $3 B, D$ ). In fact, low temperature caused large reductions in LNC in plants that did not receive extra $\mathrm{N}$ through leaf spraying, with values lower than $15 \mathrm{~g} \mathrm{~kg}^{-1}$ suggesting $\mathrm{N}$ deficiency (Santos et al. 2017). Such decrease in LNC due to cooling was even higher in leaves +3 of plants without leaf $\mathrm{N}$ supply, which would indicate the translocation of this nutrient to the younger leaves (Masclaux-Daubresse et al. 2010). Leaf N supply also increased the culm $\mathrm{N}$ concentration and maintained root $\mathrm{N}$ concentration during exposure to low temperature (Fig. 3E,F), if the overall plant $\mathrm{N}$ status changed by leaf spraying.

Leaf nitrate and ammonium concentrations were not changed by leaf $\mathrm{N}$ supply, but enhancements in concentrations of amino acids indicated that $\mathrm{N}$ supplied through leaf spraying was metabolized by sugarcane plants (Table 1). Increases in contents of amino acids were also reported in grapevine leaves sprayed with urea (Pérez-Álvarez et al. 2017). Interestingly, the concentrations of amino acids were similar at the end of exposure to low temperature (Table 1), suggesting higher amino acids consumption and $\mathrm{N}$ partitioning for synthesis and maintenance of Chl pigments (Fig. $3 A, C$ ) and photosynthetic components (Figs. $1 A, 4$ ) in plants sprayed with $\mathrm{N}$. Accordingly, our results clearly revealed a gradual reduction in Chl $a$ and $b$ contents along the exposure to low temperature only in the plants that did not receive extra $\mathrm{N}$ (Fig. $3 A, C$ ). Based on this finding, we may argue that leaf $\mathrm{N}$ supply was able to prevent Chl degradation under low temperature, improving plant ability to absorb light energy. Even though proteins are composed by amino acids, significant changes were not found in the total soluble protein contents between treatments (Table 1).

Our data also revealed the sugarcane sensitivity to low temperature and a possibility to reduce such sensitivity through leaf $\mathrm{N}$ supplying (Fig. $1 A$ ). While it 

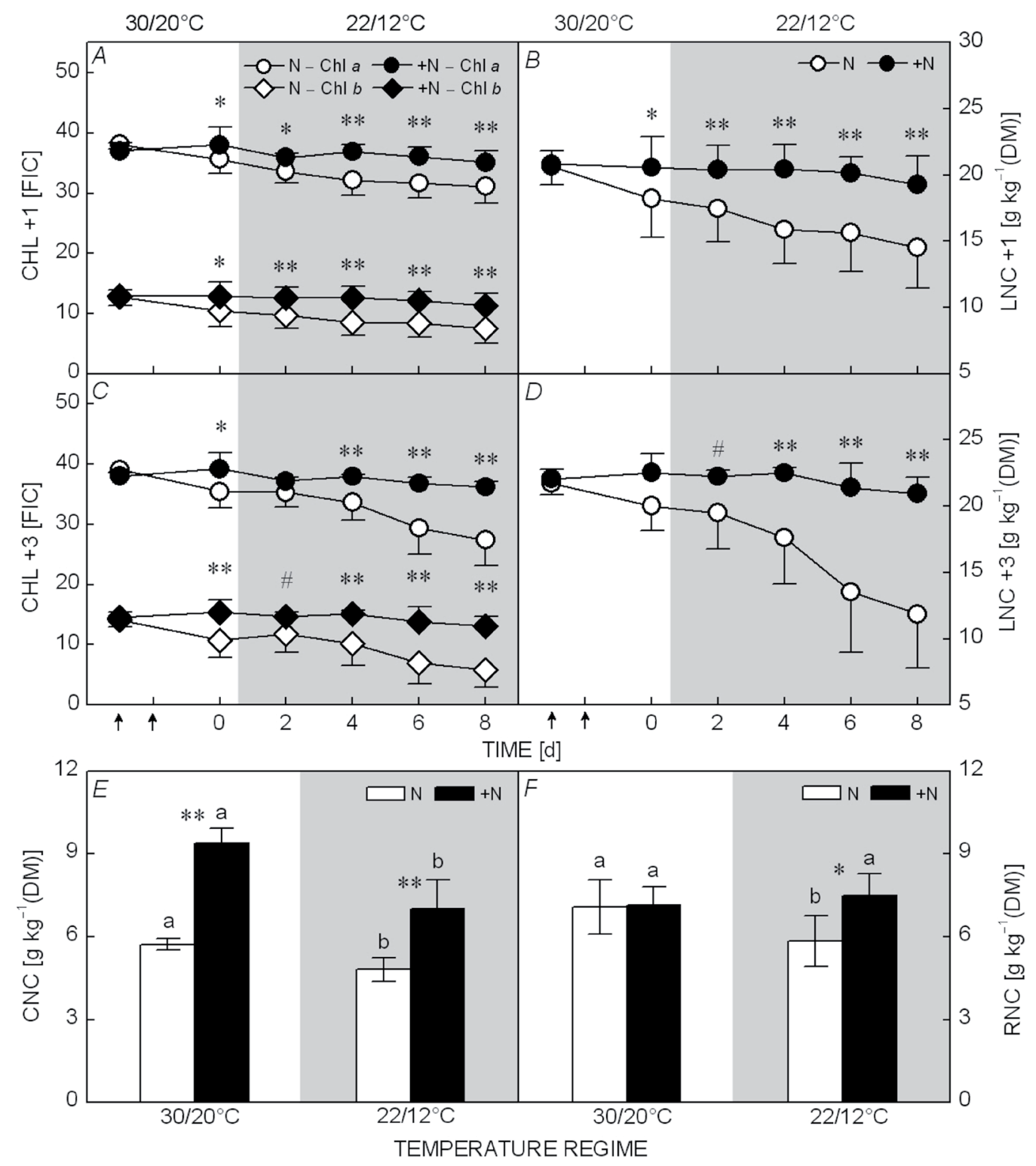

Fig. 3. Effects of leaf $\mathrm{N}$ spraying on the chlorophyll $a$ and $b$ of leaves $+1(\mathrm{CHL}+1, A)$ and $+3(\mathrm{CHL}+3, C)$, on the nitrogen concentration of leaves $+1(\mathrm{LNC}+1, B)$ and $+3(\mathrm{LNC}+3, D)$ and on the nitrogen concentration in culms $(\mathrm{CNC}, E)$ and roots $(\mathrm{RNC}, F)$ of sugarcane plants subjected to changes in growth temperature from $30 / 20^{\circ} \mathrm{C}$ to $22 / 12^{\circ} \mathrm{C}$ (day/night). Plants were sprayed with water $(\mathrm{N})$ or $2.5 \%$ urea $(+\mathrm{N})$ in two consecutive days, indicated by arrows. CNC and RNC were evaluated before cooling $\left(30 / 20^{\circ} \mathrm{C}\right)$ and after eight days at low temperature $\left(22 / 12^{\circ} \mathrm{C}\right)$. Mean values $(n=4, \pm \mathrm{SD})$ were compared by the Scott Knott's test. In $A$ to $D, * *, *$, and \# - statistical differences between the treatments in each evaluation time at $p<0.01,0.01<p<0.05$, and $0.05<p<0.10$, respectively. In $E$ and $F$, ** and * - statistical differences between the treatments at $p<0.01$ and $0.01<p<0.05$, whereas different letters show statistical difference $(p<0.05)$ between the temperature regimes. FIC - Falker chlorophyll index.

is known that increases in LNC improve photosynthetic rates in $\mathrm{C}_{4}$ species (Tazoe et al. 2006, Uribelarrea et al. 2009), we provided evidence that such benefit was also found for sugarcane plants under unfavourable thermal conditions. Stomatal responses were similar to those found for photosynthesis under low temperature (Fig. 1B), with stomatal closure being a likely consequence of coldinduced synthesis of abscisic acid (Ashraf and Harris 2013). Plants supplied with $\mathrm{N}$ presented higher $g_{\mathrm{s}}$ than that of the nonsupplied ones (Fig. $1 B$ ) and this would be a reason for the higher photosynthetic activity of $+\mathrm{N}$ plants, as found in Miscanthus (Feng et al. 2012). However, we did not find any increase in intercellular $\mathrm{CO}_{2}$ availability due to higher stomatal aperture, which would justify high photosynthetic rates. $C_{\mathrm{i}}$ varied between 129 and 195 $\mu \mathrm{mol}\left(\mathrm{CO}_{2}\right) \mathrm{mol}^{-1}$ in $\mathrm{N}$ plants and between 131 and 172 $\mu \mathrm{mol}\left(\mathrm{CO}_{2}\right) \mathrm{mol}^{-1}$ in $+\mathrm{N}$ plants. In general, exposure to low temperature increased $C_{\mathrm{i}}$ - as found in Flaveria bidentis L. (Kubien et al. 2003) - and this response accompanied by reductions in $P_{\mathrm{N}}$ suggests nonstomatal limitation of 
Table 1. Leaf concentrations of $\mathrm{NO}_{3}^{-}, \mathrm{NH}_{4}^{+}$, amino acids, and total soluble protein as affected by leaf $\mathrm{N}$ spraying on sugarcane plants under $30 / 20^{\circ} \mathrm{C}$ to $22 / 12^{\circ} \mathrm{C}$ (day/night). Plants were sprayed with water (treatment $\mathrm{N}$ ) or $2.5 \%$ urea (treatment $+\mathrm{N}$ ) in two consecutive days before cooling. Evaluations were performed before $\left(30 / 20^{\circ} \mathrm{C}\right)$ and $8 \mathrm{~d}$ after reducing temperature $\left(22 / 12^{\circ} \mathrm{C}\right)$. The average values $(n=4, \pm \mathrm{SD})$ were compared by the Scott Knott's test $(p<0.05)$. Different capital letters show statistical difference between the treatments in each thermal regime, and different lowercase letters show difference between the temperature regimes in each treatment.

\begin{tabular}{llll}
\hline Variable & \multicolumn{2}{l}{$\begin{array}{l}\text { Temperature } \\
(\text { day/night })\left[{ }^{\circ} \mathrm{C}\right]\end{array}$} & \multicolumn{2}{l}{ Treatment } \\
& & $\mathrm{N}$ & $+\mathrm{N}$ \\
\hline $\mathrm{NO}_{3}{ }^{-}\left[\mu \mathrm{mol} \mathrm{g}^{-1}(\mathrm{FM})\right]$ & $30 / 20$ & $9.7 \pm 2.0^{\mathrm{Ab}}$ & $11.1 \pm 1.8^{\mathrm{Aa}}$ \\
& $22 / 12$ & $14.6 \pm 2.4^{\mathrm{Aa}}$ & $14.4 \pm 3.9^{\mathrm{Aa}}$ \\
$\mathrm{NH}_{4}{ }^{+}\left[\mu \mathrm{mol} \mathrm{g}^{-1}(\mathrm{FM})\right]$ & $30 / 20$ & $0.2 \pm 0.1^{\mathrm{Aa}}$ & $0.3 \pm 0.1^{\mathrm{Aa}}$ \\
& $22 / 12$ & $0.2 \pm 0.0^{\mathrm{Aa}}$ & $0.3 \pm 0.1^{\mathrm{Aa}}$ \\
Amino acids $\left[\mu \mathrm{mol} \mathrm{g}{ }^{-1}(\mathrm{FM})\right]$ & $30 / 20$ & $4.6 \pm 0.5^{\mathrm{Ba}}$ & $18.8 \pm 4.8^{\mathrm{Aa}}$ \\
& $22 / 12$ & $3.4 \pm 0.4^{\mathrm{Aa}}$ & $4.6 \pm 2.0^{\mathrm{Ab}}$ \\
Protein $\left[\mathrm{mg} \mathrm{g}^{-1}(\mathrm{FM})\right]$ & $30 / 20$ & $7.4 \pm 3.1^{\mathrm{Aa}}$ & $7.9 \pm 2.0^{\mathrm{Aa}}$ \\
& $22 / 12$ & $6.4 \pm 1.0^{\mathrm{Aa}}$ & $8.3 \pm 0.6^{\mathrm{Aa}}$ \\
\hline
\end{tabular}

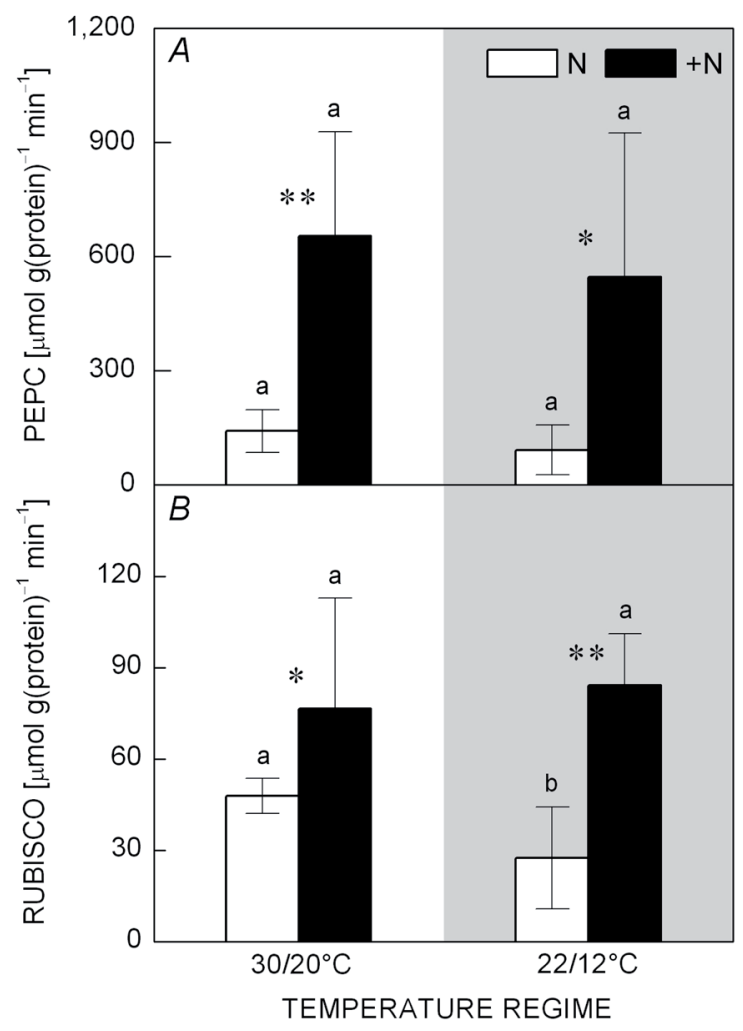

Fig. 4. Effects of leaf N spraying on the activities of PEPC $(A)$ and Rubisco $(B)$ of sugarcane plants subjected to changes in growth temperature from $30 / 20^{\circ} \mathrm{C}$ to $22 / 12^{\circ} \mathrm{C}$ (day/night). Plants were sprayed with water $(\mathrm{N})$ or $2.5 \%$ urea $(+\mathrm{N})$ in two consecutive days, before cooling. Samples were taken before cooling $\left(30 / 20^{\circ} \mathrm{C}\right)$ and after eight days at low temperature $\left(22 / 12^{\circ} \mathrm{C}\right)$. Mean values $(n=4, \pm \mathrm{SD})$ were compared by the Scott Knott's test. ** and * statistical differences between the treatments in each temperature regime at $p<0.01$ and $0.01<p<0.05$, respectively. Different letters show statistical difference $(p<0.10)$ between the temperature regimes.

photosynthesis.

Regarding the primary photochemistry, decreases
Table 2. Number of active leaves of the main culm, number of culms, main culm height, total leaf area and leaf, culm and root dry matter (DM) of sugarcane plants sprayed with $\mathrm{N}$ and subjected to cooling for eight days. Plants were sprayed with water (treatment $\mathrm{N}$ ) or $2.5 \%$ urea (treatment $+\mathrm{N}$ ) in two consecutive days before cooling. The average values $(n=4, \pm \mathrm{SD})$ were compared by the Scott Knott's test $(* 0.05<p<0.10$ and $* * p<0.05)$. Different capital letters show statistical difference between the treatments.

\begin{tabular}{lll}
\hline Variable & $\begin{array}{l}\text { Treatment } \\
\end{array}$ & $\mathrm{N}$ \\
\hline Leaf [units] $^{*}$ & $4.3 \pm 0.5^{\mathrm{B}}$ & $5.3 \pm 0.5^{\mathrm{A}}$ \\
Culm [units] $^{\mathrm{A}}$ & $15.5 \pm 5.4^{\mathrm{A}}$ & $11.5 \pm 3.1^{\mathrm{A}}$ \\
Plant height [cm]* & $41.0 \pm 2.4^{\mathrm{B}}$ & $45.8 \pm 2.8^{\mathrm{A}}$ \\
Leaf area [m $\left.{ }^{2}\right]^{* *}$ & $0.52 \pm 0.06^{\mathrm{B}}$ & $0.63 \pm 0.08^{\mathrm{A}}$ \\
Leaf DM [g] & $94.3 \pm 13.9^{\mathrm{A}}$ & $103.3 \pm 16.0^{\mathrm{A}}$ \\
Stem DM [g] & $57.8 \pm 7.8^{\mathrm{A}}$ & $66.2 \pm 7.8^{\mathrm{A}}$ \\
Root DM [g] & $31.1 \pm 7.4^{\mathrm{A}}$ & $31.5 \pm 7.4^{\mathrm{A}}$ \\
\hline
\end{tabular}

in $\mathrm{F}_{\mathrm{v}} / \mathrm{F}_{\mathrm{m}}$ and $\Delta \mathrm{F} / \mathrm{F}_{\mathrm{m}}$, with cooling (Fig. 2A,B) indicate thermoinhibition of PSII activity and likely reductions in ATP synthesis and RuBP regeneration (Allen and Ort 2001). Only marginal effects of leaf $N$ supply were found on photochemical activity, with $\mathrm{N}$-supplied plants showing higher $\mathrm{F}_{\mathrm{v}} / \mathrm{F}_{\mathrm{m}}$ only at the beginning of cold exposure (Fig. 2A). On the other hand, leaf N supply had significant effects on biochemistry of photosynthesis. Due to higher leaf $\mathrm{N}$ status during cooling, plants supplied with $\mathrm{N}$ showed maintenance of PEPC activity and higher Rubisco activity under low temperature (Fig. 4).

$\mathrm{C}_{4}$ plants have a mechanism of $\mathrm{CO}_{2}$ concentration that increases the catalytic capacity of Rubisco, minimizing its oxygenase activity (photorespiration) and maximizing the carboxylation during the photosynthetic process. Such physiological advantage is possible due to PEPC, which catalyses the initial carboxylation of $\mathrm{CO}_{2}$ after the action of a carbonic anhydrase in mesophyll cells (Sage et al. 2012). As Rubisco is less abundant in $\mathrm{C}_{4}$ species as compared to $\mathrm{C}_{3}$ species and both PEPC and Rubisco lose activity under low temperature (Sage and Pearcy 1987, Sage 2002, Sage 
and Kubien 2007), those two enzymes have an important role in $\mathrm{C}_{4}$ photosynthesis under stressful conditions. Taken together, our results indicate that the photosynthetic reactions in both mesophyll and bundle sheath cells of sugarcane were improved by leaf $\mathrm{N}$ supply, with increases in carbon pumping from mesophyll to bundle sheath cells by PEPC and consequent maintenance of Rubisco activity under low temperature (Fig. 4). Large differences found in PEPC and Rubisco activity due to nitrogen supply would be checked in vivo through $P_{\mathrm{N}}-C_{\mathrm{i}}$ response curves, when photosynthetic reactions are not necessarily occurring under optimum conditions, as in our biochemical assays. In addition, the causes of increased carboxylation activity under $+\mathrm{N}$ conditions would be further investigated, considering upregulation of gene expression, increases in amount of those specific enzymes and/or their higher activity.

Leaf $\mathrm{N}$ supply did not change biomass accumulation in sugarcane under low temperature (Table 2), even with plants showing increases in photosynthetic activity (Fig. 1A). In fact, leaf $\mathrm{N}$ spraying enhanced the number of leaves and leaf area without significantly changing biomass. Such absence of positive effects of leaf N supply on plant growth could be justified by the short period of experimentation, i.e. eight days. Thus, further research is needed to reveal how the nutritional management with leaf $\mathrm{N}$ supply would affect biomass production and yield of field-grown sugarcane plants.

In conclusion, stomatal, photochemical, and biochemical limitations were responsible for low photosynthesis of sugarcane under low temperature. However, leaf $\mathrm{N}$ supply was able to decrease the sensitivity of photosynthesis to cooling, impeding reductions in leaf $\mathrm{N}$ and chlorophyll concentrations and increasing the activity of Rubisco and PEPC. Those results suggest that leaf $\mathrm{N}$ supply could increase the light-conversion efficiency into biomass - in which photosynthesis is the main component - in sugarcane fields, where low temperature occurs during the winter season and photoassimilate supplying is critical for sucrose yield.

\section{References}

Allen D.J., Ort D.R.: Impacts of chilling temperatures on photosynthesis in warm-climate plants. - Trends Plant Sci. 6: 36-42, 2001.

Allison J.C.S., Williams H.T., Pammenter N.W.: Effect of specific leaf nitrogen content on photosynthesis of sugarcane. - Ann. Appl. Biol. 131: 339-350, 1997.

Ashton A.R., Burnell J.N., Furbank R.T. et al.: Enzymes of $\mathrm{C}_{4}$ photosynthesis. - In: Dey P.M, Harborne, J.B. (ed.): Methods in Plant Biochemistry: Enzymes of Primary Metabolism Pp. 39-72. Academic Press, Lancaster 1990.

Ashraf M., Harris P.J.C.: Photosynthesis under stressful environments: an overview. - Photosynthetica 51: 163-190, 2013.

Bonnett G.D.: Developmental stages (phenology). - In: Moore P.H., Botha F.C. (ed.): Sugarcane: Physiology, Biochemistry, and Functional Biology Pp. 35-53. John Wiley \& Sons, Ames 2014.

Bradford M.M.: A rapid and sensitive method for the quantitation of microgram quantities of protein utilizing the principle of protein-dye binding. - Anal. Biochem. 72: 248-254, 1976.

Bremner J.M.: Total nitrogen. - In: Black C.A. (ed.): Methods of Soil Analysis. Pp. 1149-1178. American Society of Agronomy, Madison 1965.

Cataldo D.A., Maroon M., Schrader L.E. et al.: Rapid colorimetric determination of nitrate in plant tissue by nitration of salicylic acid. - Commun. Soil Sci. Plant Anal. 6: 71-80, 1975.

Cerqueira G., Santos M.C., Marchiori P.E.R. et al.: Estimating nitrogen concentration in sugarcane leaves through chlorophyll readings. - In: XVI Brazilian Congress of Plant Physiology. Pp. 63-64. Brazilian Society of Plant Physiology, São Pedro 2017.

Cocking E.C, Yemm E.W.: Estimation of amino acids by ninhydrin. - Biochem. J. 58: 12-12, 1954.

Crawford N.M., Kahn M.L., Leustek T. et al.: Nitrogen and sulfur assimilation. - In: Buchanan B.B., Gruissem W., Jones R.L. (ed.): Biochemistry and Molecular Biology of Plants. Pp. 786-849. American Society of Plant Biologists, Rockville 2000.

Degl'Innocenti E., Guidi L., Soldatini G.F.: Effect of chronic $\mathrm{O}_{3}$ fumigation on the activity of some Calvin cycle enzymes in two poplar clones. - Photosynthetica 40: 121-126, 2002.

Feng X.P., Chen Y., Qi Y.H. et al.: Nitrogen enhanced photosynthesis of Miscanthus by increasing stomatal conductance and phosphoenolpyruvate carboxylase concentration. Photosynthetica 50: 577-586, 2012.

Ferreira D.F.: Sisvar: a computer statistical analysis system. Cienc. Agrotecnol. 35: 1039-1042, 2011.

Kubien D.S., von Caemmerer S., Furbank R.T. et al: $\mathrm{C}_{4}$ photosynthesis at low temperature. A study using transgenic plants with reduced amounts of Rubisco. - Plant Physiol. 132: $1577-1585,2003$.

Magalhães Filho J.R.: [Efficiencies associated with sugarcane productivity and canopy architecture.] - $\mathrm{PhD}$ Thesis. Agronomic Institute, Campinas 2014. [In Portuguese]

Maranville J.W., Madhavan S. Physiological adaptations for nitrogen use efficiency in sorghum. - In: Adu-Gyamfi J.J. (ed.): Food Security in Nutrient-Stressed Environments: Exploiting Plants' Genetic Capabilities. Pp. 81-90. Kluwer Academic Publishers, Dordrecht 2002.

Marchiori P.E.R., Machado E.C., Ribeiro R.V.: Photosynthetic limitations imposed by self-shading in field-grown sugarcane varieties. - Field Crop. Res. 155: 30-37, 2014.

Masclaux-Daubresse C., Daniel-Vedele F., Dechorgnat J. et al.: Nitrogen uptake, assimilation and remobilization in plants: challenges for sustainable and productive agriculture. - Ann. Bot.-London 105: 1141-1157, 2010.

McCullough H.: The determination of ammonia in whole blood by a direct colorimetric method. - Clin. Chim. Acta 17: 297 304, 1967.

Park S.E., Robertson M., Inman-Bamber N.G.: Decline in the growth of a sugarcane crop with age under high input conditions. - Field Crop. Res. 92: 305-320, 2005.

Pérez-Álvarez E.P., Garde-Cerdán T., García-Escudero E. et al.: Effect of two doses of urea foliar application on leaves and grape nitrogen composition during two vintages. - J. Sci. Food Agri. 97: 2524-2532, 2017.

Reid C.D., Tissue D.T., Fiscus E.L. et al: Comparison of spectrophotometric and radioisotopic methods for the assay of Rubisco in ozone-treated plants. - Physiol. Plantarum 101: 398-404, 1997.

Robinson N., Vogt J., Lakshmanan P. et al.: Nitrogen physiology of sugarcane. - In: Moore P.H., Botha F.C. (ed.): Sugarcane: Physiology, Biochemistry \& Functional Biology. Pp. 169195. Wiley Blackwell, Oxford 2014. 
Roháček K.: Chlorophyll fluorescence parameters: the definitions, photosynthetic meaning, and mutual relationships Photosynthetica 40: 13-29, 2002.

Sage R.F.: Variation in the k(cat) of Rubisco in $\mathrm{C}_{3}$ and $\mathrm{C}_{4}$ plants and some implications for photosynthetic performance at high and low temperature. - J. Exp. Bot. 53: 609-620, 2002.

Sage R.F., Sage T.L., Kocacinar F.: Photorespiration and the evolution of $\mathrm{C}_{4}$ photosynthesis. - Annu. Rev. Plant Biol. 63: 19-47, 2012.

Sage R.F., Kubien D.S.: The temperature response of $\mathrm{C}_{3}$ and $\mathrm{C}_{4}$ photosynthesis. - Plant Cell Environ. 30: 1086-1106, 2007.

Sage R.F., Pearcy R.W.: The nitrogen use efficiency of $\mathrm{C}_{3}$ and $\mathrm{C}_{4}$ plants: II. Leaf nitrogen effects on the gas exchange characteristics of Chenopodium album (L.) and Amaranthus retroflexus (L.). - Plant Physiol. 84: 959-963, 1987.

Sage R.F., Peixoto M.M., Sage T.L.: Photosynthesis in sugarcane - In: Moore P.H., Botha F.C. (ed.): Sugarcane: Physiology, Biochemistry and Functional Biology. Pp. 121-154. WileyBlackwell, Chichester 2013.

Sage R.F., Sharkey T.D., Seemann J.R.: The in-vivo response of the ribulose-1,5-biphosphate carboxylase activation state and the pool sizes of photosynthetic metabolites to elevated $\mathrm{CO}_{2}$ in Phaseolus vulgaris L. - Planta 174: 407-416, 1988.

Sage R.F., Way D.A., Kubien D.S.: Rubisco, Rubisco activase, and global climate change. - J. Exp. Bot. 59: 1581-1595, 2008.

Sage R.F., Wedin D.A., Li M.: The biogeography of $\mathrm{C}_{4}$ photosynthesis, patterns and controlling factors. - In: Sage R.F., Monson R.K. (ed.): $C_{4}$ Plant Biology. Pp. 313-373. Academic Press, Toronto 1999.

Sales C.R.G., Ribeiro R.V., Silveira J.A.G. et al:: Superoxide dismutase and ascorbate peroxidase improve the recovery of photosynthesis in sugarcane plants subjected to water deficit and low substrate temperature. - Plant Physiol. Bioch. 73: 326-336, 2013.

Saliendra N.Z., Meinzer F.C., Perry M. et al.: Associations between partitioning of carboxylase activity and bundle sheath leakiness to $\mathrm{CO}_{2}$, carbon isotope discrimination, photosynthesis, and growth in sugarcane. - J. Exp. Bot. 47: 907-914, 1996.

Santos M.C., Cerqueira G., Marchiori P.E.R. et al.: Excessive nitrogen fertilization reduces root growth without affecting sugarcane photosynthesis. - In: XVI Brazilian Congress of Plant Physiology. Pp. 64. Brazilian Society of Plant Physiology, São Pedro 2017.

Sharkey T.D., Seemann J.R., Berry J.A.: Regulation of ribulose1,5-bisphosphate carboxylase activity in response to changing partial pressure of $\mathrm{O}_{2}$ and light in Phaseolus vulgaris. - Plant Physiol. 81: 788-791, 1986.

Tazoe Y., Noguchi K., Terashima I.: Effects of growth light and nitrogen nutrition on the organization of the photosynthetic apparatus in leaves of a $\mathrm{C}_{4}$ plant, Amaranthus cruentus. Plant Cell Environ. 29: 691-700, 2006.

Uribelarrea M., Crafts-Brandner S.J., Below F.E.: Physiological $\mathrm{N}$ response of field-grown maize hybrids (Zea mays L.) with divergent yield potential and grain protein concentration. Plant Soil 316: 151-160, 2009.

van Heerden P.D.R., Donaldson R.A., Watt D.A. et al: Biomass accumulation in sugarcane: unravelling the factors underpinning reduced growth phenomena. - J. Exp. Bot. 61: 2877-2887, 2010.

Weatherburn M.W.: Phenol-hypochlorite reaction for determination of ammonia. - Anal. Chem. 39: 971-974, 1967.

(C) The authors. This is an open access article distributed under the terms of the Creative Commons BY-NC-ND Licence. 